\title{
Plasmodesmata: Symplastic Transport of Herbicides within the Plant
}

\author{
Germani Concenco ${ }^{1}$ and Leandro Galon ${ }^{2}$ \\ ${ }^{1}$ D.Sc in Crop Production, International Researcher at Valmont Industries, Omaha, NE, \\ ${ }^{2}$ D.Sc. in Crop Production, Professor at Federal University of Pampa - UNIPAMPA \\ 1USA \\ ${ }^{2}$ Brazil
}

\section{Introduction}

When studying herbicide absorption, translocation, metabolism, and mode of action, transport pathways are usually referred to as apoplast (dead cells) and symplast (living cells) as simple synonyms of xylem and phloem. However, the behavior of an herbicide within a plant greatly depends upon several factors and its movement accomplished by different routes and processes.

If an herbicide takes too long to be absorbed after application, it will be more available for processes that would greatly reduce its absorption - rain, hot sun, and wind, among others. After the herbicide is absorbed, it needs to be quickly translocated from the point it was absorbed to the site of action. If it is not, chemical processes will take care of transforming the herbicide into non-toxic or less-toxic metabolites.

For a quick and efficient translocation, several pathways act together in a relatively dependent manner - everything is connected at different degrees of the plant's metabolic rate by the time reactions occur. For example, when a plant is under water stress, it may react differently to the same dose of herbicide usually applied to that species. In addition, phloem will only translocate an herbicide quickly if this compound is efficiently loaded into the phloem. From the leaf surface to the site of action, herbicide movement involves passage through the apoplast and symplast by several pathways, one of which is via plasmodesmata.

In the classical concept of Munch (1930), plasmodesmata are considered to form simple cytoplasmic bridges between neighboring plant cells in order to create the symplasm. This concept has dominated, if not monopolized, the thinking of plant biologists and, in particular, plant physiologists over the last few decades. Recent advances in ultra-structural, physiological, and molecular studies on plasmodesmata indicate that this simple view is in need of revision (Lucas, 1993). Plasmodesmata are plasma channels connecting neighboring cells that allow the exchange of informational, functional, and structural molecules and xenobiotics among cells of the same "group" (domain), both apoplastically and symplastically. Cells of the same domain behave as functional units, and substances are able to move between them at rates above the observed for trans-membrane movement. Plasmodesmata participate symplastically in long-distance movement, both by association with phloem and interchange between neighboring domains. When the plant is under stress, and xylem and phloem flux is slower, plasmodesmata could be more participative in 
long-distance translocation of systemic herbicide molecules. Plasmodesmata play a crucial role in transporting materials and signaling molecules intercellularly in higher plants. In the last decade, it has been discovered that plasmodesmal function is much more complex than previously thought, and more molecular and in vivo studies are necessary to discern the absolute structure and function of these interesting cytoplasmic channels (Hannahs, 1997). The importance and role plasmodesmata play on intercellular transport of molecules including molecules of herbicides - are explored in this chapter.

\section{Herbicide absorption and translocation}

The biological activity of herbicide within a plant is a function of absorption, translocation, metabolism, and susceptibility of the plant to the herbicide and/or to its metabolites. Because of that, the simple act of an herbicide reaching the leaf surface - or roots, in the case of a soil-applied herbicide - does not guarantee its effective action (Silva et al., 2007). The herbicide needs to be absorbed and translocated to reach the organelle where it will express its herbicidal activity. An active ingredient may affect several metabolic processes within the plant; however, the first biophysical lesion it causes will usually characterize its mechanism of action (Ferreira et al., 2008). The place where an herbicide effectively inhibits a biological process receives the name "site of action" (Hager \& Sprague, 2002).

The main route of herbicide penetration in plants depends on a series of factors related to the plant, environment, and characteristics of the herbicide formulation and chemistry (Silva et al., 2007). After the herbicide passes through the first barrier - usually the cuticle - it should be moved to the site of action. Young plants incapable of regenerating from buried organs (tubercules, bulbs, rhizomes) after an herbicide application may easily be killed by a contact herbicide, once adequate coverage of the plant is reached during the application. For plants capable of regenerating from reserve organs, however, a given amount of herbicide must be able to move from the point where it was absorbed to the buried organs to ensure that the plant will be killed as a whole (Silva et al., 2007). In this case, the long-distance transport is even more important for efficient herbicide activity.

In a simplified way, the movement of an herbicide within the plant can be accomplished by two main routes: apoplast and symplast. Apoplast is a group of dead cells - including cell walls, intercellular spaces, and xylem - which form a continuum where water and solutes have the ability to move (Jachetta, 1986). Symplast is defined as the total mass of living cells in a plant, which forms a long and complex net along the plant both through phloem and through direct connections between neighboring cells that are usually in the same organ plasmodesmata (Hay, 1976). These structures are also responsible for connecting neighboring cells in the phloem to form the continuum vase along the plant.

The main representatives of the apoplast and symplast are respectively xylem and phloem, and transportation through these routes is not completely independent - xylem-to-phloem transfer cells usually occur in specific parts of the plant (Figure 1). Since the translocation by xylem is unidirectional (from roots to leaves), it may be considered secondarily important for translocation of leaf-applied herbicides to fast-growing organs with low rates of respiration, such as buds, flowers, or fruits (Neumann, 1988). This task is fulfilled by the phloem. Some herbicides may present completely distinct behavior in relation to translocation as a function of the way they are being translocated. For example, atrazine behaves as a contact herbicide when applied to leaves (not translocated through phloem), but assumes a systemic behavior (meaning it moves within xylem) when applied to roots (Silva et al., 2007). 


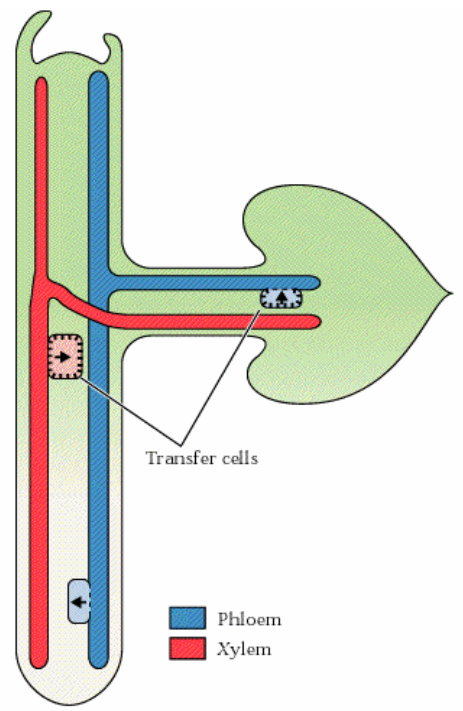

Fig. 1. Important sites of xylem-to-phloem solute transfer occur at leaf traces and minor veins of leaves. Source: Buchanan (2005).

The phloem is a network comprised of living cells, which goes from the tip of the root to the end of the leaves; within this network, translocation of photosynthates and many compounds occurs via sieve plates on both ends of the cells. Translocation through phloem is fundamental in the distribution of either natural or synthetic chemical compounds from mature leaves to growth regions in roots and stem (Vidal, 2002). There are mathematical models that allow efficient calculation of translocation rates of xenobiotics via phloem, according to membrane permeability, size of the phloem loading area, and other parameters (Tyree et al., 1979).

After the herbicidal molecule is translocated via phloem and entered into an adjacent cell, neighboring cells also need to be achieved to allow for proper action of the herbicide. This movement, which is usually a short distance, can be done through four primary ways: (1) apoplastic distribution or mass flow; (2) passive diffusion in favor of an electro-chemical gradient; (3) active translocation involving protein carriers at the expense of ATPs; and (4) movement and broadcast via plasmodesmata (Figure 2).

Both apoplastic and passive diffusion, in favor of an electro-chemical gradient, allow for relatively slow rates of movement for both molecules bigger than simple ions, whose size typically reaches only a few dozen Daltons (Da), and small molecules with an electric charge. These diffusions include passage by the plasma membrane of the cell of origin, cell wall (a tangle of cellulosic fibers stabilized normally by hemicellulose and pectin), middle lamella, and the cell wall and plasma membrane of the destination cell (Buchanan et al., 2005). Maximum rates of translocation through the membrane are approximately $1.0 \times 10^{-8} \mathrm{~cm}$ $\mathrm{s}^{-1}$ for ions such as $\mathrm{K}^{+}$and $\mathrm{Na}^{+}$(Taiz \& Zeiger, 2004). The actual rate of movement observed for glyphosate through the membranes is $1.7 \times 10^{-8} \mathrm{~cm} \mathrm{~s}^{-1}$, or $0.0006 \mathrm{~mm} \mathrm{~h}^{-1}$, which is very similar to the observed rates for $\mathrm{K}^{+}$and $\mathrm{Na}^{+}$(Gougler \& Geiger, 1981). Each membrane has a characteristic composition of proteins and lipids, making translocation also dependent on tissue or organs (Alberts et al., 1999). Active translocation can contribute to the movement of 
glyphosate to the interior of the cell. Inside this category of xenobiotics, this herbicide possesses the rare abilityof transposing the plasma membrane via a protein carrier. Due to phosphate carriers contained in the plasma membrane, a link is created between glyphosate and the carrier, translocating it to the cytoplasm (Denis \& Delrot, 1993).

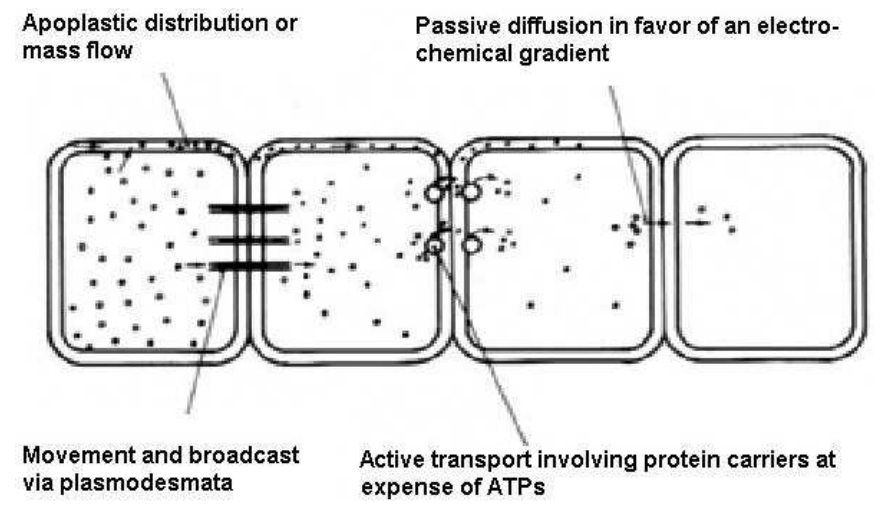

Fig. 2. Possible ways of herbicide translocation between plant cells. Among the depicted processes, only the active translocation at the expense of ATP demands energy. Source: Neumann, 1988.

\section{Plasmodesmata}

In a simple way, plasmodesmata are plasma membrane channels that pass through the cell wall, which not only allow for communication between plant cells, but also facilitate direct intercellular translocation of ions, photosynthates, growth regulators, and macromolecules of xenobiotics with similar characteristics (Robards, 1976). They provide a direct cytoplasmic connection between neighboring cells through cell walls. The properties of these communication channels are a factor in the establishment of the so-called "symplastic domains" - a group of cells that communicate and act as a physiological development unit with the ability of translocating macroproteins and RNA (Figure 3). Cells of the same domain are able to freely exchange information with each other while the communication is restricted between domains, occurring by translocation through the cell wall (Oparka \& Roberts, 2001).

A typical plant cell may have between $10^{3}$ and $10^{5}$ plasmodesmata connecting it with adjacent cells, equaling between 1 and 10 per $\mu \mathrm{m}^{2}$. Plasmodesmata are approximately $40-$ $60 \mathrm{~nm}$ in diameter at the mid-point and are constructed of three main layers: the plasma membrane, the cytoplasmic sleeve, and the desmotubule (central rod). They can transverse cell walls that are up to 90nm thick (Robards, 1976). There are three classical schematic models which try to clarify the plasmodesma structure (Figure 4).

The symplastic transport of substances through plasmodesmata can occur in two ways: via cytoplasmic connection or via endoplasmic reticulum. In Figure 3, two distinct regions can be seen at the canal of plasmodesma: (1) a cytoplasmic sleeve, which connects the cytoplasm of neighboring cells, and (2) a central rod, which connects the endoplasmic reticulum of neighboring cells. Concerning the herbicide transport, the cytoplasmic connection is the important route for symplastic transport of herbicides from cell to cell, via plasmodesmata. 

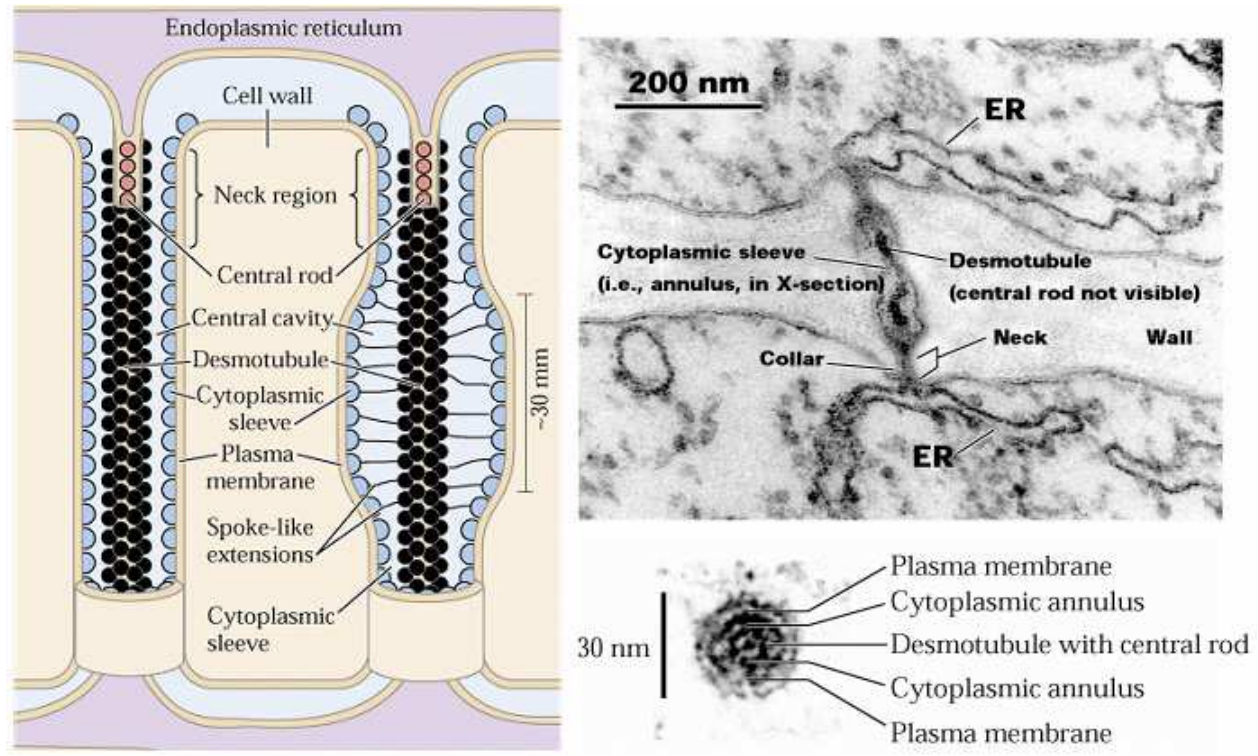

Fig. 3. Schematics depicting how plasmodesmata connect cytoplasms of neighboring cells. A plasmodesmata's pore diameter averages $50 \mathrm{~nm}$ and allows diffusion of water and small molecules among cells. In order to allow translocation of molecules that are larger than the exclusion limit, the diameter of the pore can be modified by rearranging proteins connected to the inner surface of the pore. Affinity between some compounds and proteins in the inner surface of the canal make possible the flux of molecules larger than the Size Exclusion Limit (SEL). Source: Buchanan (2005).
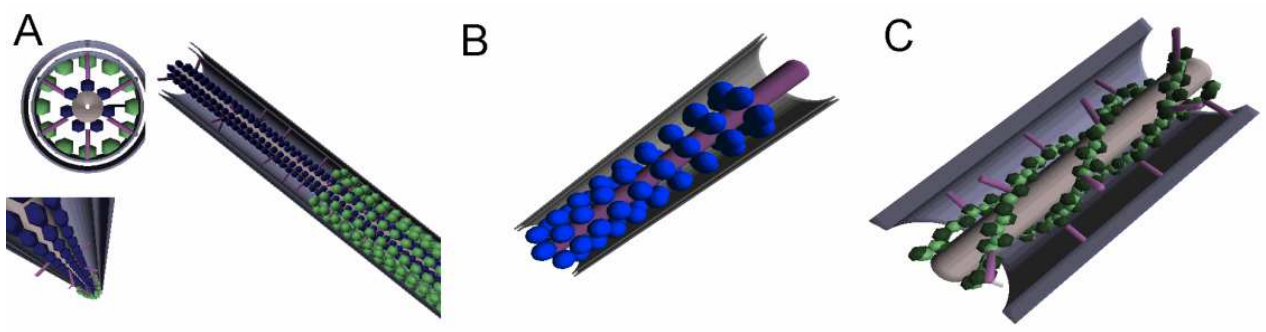

Fig. 4. Computer-generated models of the plasmodesmata structure, used for describing the three-dimensional characteristics of the plasmodesmal canal. (A) Ding model; (B) Overall model; (C) Radford model. All models depict the central rod (endoplasmic reticulum) and the space between the central rod and the cell wall (filled with cytoplasm). Source: Hannah (1997).

Plasmodesmata are not randomly scattered in a cell wall, but are rather grouped in specific points called "punctuations" or "pits." Plasmodesmata are formed when portions of the endoplasmic reticulum are trapped across the middle lamella as new cell wall is laid down between two newly divided plant cells; these eventually become the cytoplasmic 
connections between cells (primary plasmodesmata). Here, the wall is not further thickened, and depressions, or thin areas ("pits"), are formed in the walls; depressions normally couple between adjacent cells. Alternatively, plasmodesmata can be inserted into existing cell walls between non-dividing cells (Lucas et al., 1993). It is usually the formation of secondary plasmodesmata, which appear after a secondary wall is created. In grafting for example, two mature cells are side-by-side and are obliged to establish communication between each other (Figure 5). In this situation, the secondary wall is thinned and a new pit field is formed (Buchanan, 2005).
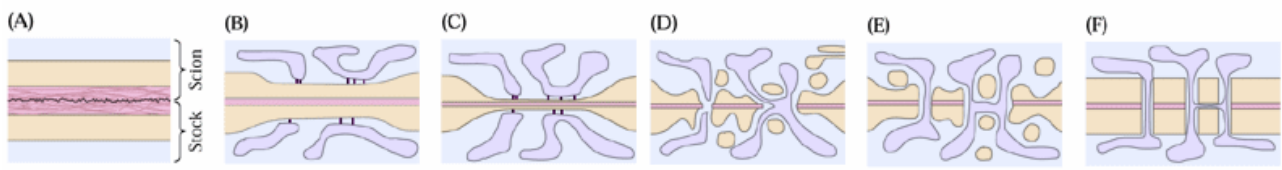

Fig. 5. Formation of a new punctuation field - "pit" (C) and secondary plasmodesmata (D, E, F) in mature cells. Source: Adapted from Buchanan (2005).

Recent studies have launched new visions about symplastic isolation and traffic of large molecules during the growth and development of a plant, confirming the role of plasmodesmata in controlling and mediating intercellular communication (Kragler et al., 1998; Tan et al., 2005). The greatness of the flow via plasmodesmata is usually measured by either a comparison between independent fluxes, which are estimated by concentration gradients, and diffusion coefficients, or by the hydrodynamic radius of the molecule, which is the amount of water a molecule carries around itself (Hatch \& Slack, 1970; Terry \& Robards, 1987). The size exclusion limit (SEL) of plasmodesmata corresponds to the maximum size of a "non-favored" molecule that is capable of crossing the plasmodesma and is both linked directly to the diameter of the canal and the affinity between the molecule and proteins embedded in the interior of the pore (Figure 3). The most accepted theory among researchers is only molecules smaller than $1 \mathrm{kDa}$ (kiloDalton) move freely among cells of the same domain (Oparka \& Roberts, 2001). However, molecules greater than $1 \mathrm{kDa}$ can pass through plasmodesmata if they have some degree of affinity with proteins embedded in the canal (Taiz \& Zeiger, 2004; Buchanan, 2005).

In addition, the SEL decreases with increasing age of the organ; for example, newer parts of the plant have the ability to carry larger molecules (Crawford \& Zambrysky, 2001). This may help explain why plants become less susceptible to herbicides at more advanced stages of development. Formation of a less permeable, thicker secondary wall, among other factors, also limits the translocation of herbicides in older plants. These factors contribute to larger herbicide doses that are required to control older plants, until a certain point of development (Chamel, 1988). At maturity, plasmodesmata present very low conductance and contribute to a small extent for systemic distribution of large molecules. In addition, the conductance depends not only on the diameter of the canal, but also on the affinity between the molecules being conducted and the proteins embedded in the interface of the canal.

In addition to the presence of symplastic transport through plasmodesmata, apoplastic transport is also present, as shown in Figure 6. However, at the time of this publication, no studies were found to explore this pathway of transport via plasmodesmata in relation to apoplastic herbicide translocation. 


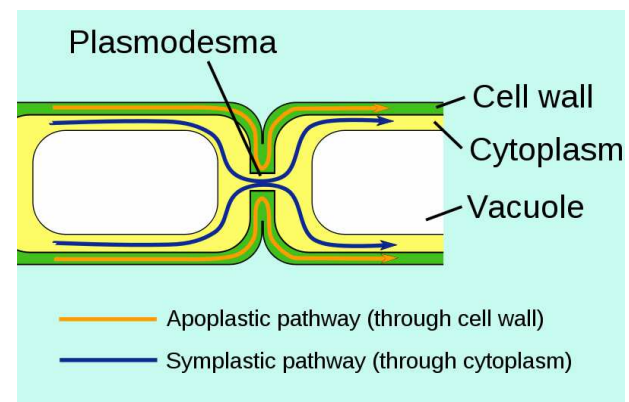

Fig. 6. Schematics showing symplastic and apoplastic movement pathways via cell-to-cell communication (plasmodesmata). Source: Wikipedia, licensed under GPL terms (2010).

\section{Herbicide translocation through plasmodesmata}

All herbicides applied to the leaves of plants with $C_{4}$ metabolism must penetrate the vascular bundle sheath cells in order to achieve xylem and/or phloem (Vidal, 2002). Once these cells are highly lignified (suberin may also occur in some monocots), the movement of the herbicide molecules from cells in the mesophyl to the cells of the vascular bundle sheath occurs exclusively by plasmodesmata present this interface (Osmond \& Smith, 1976). This is the only way the herbicide can reach the phloem, which is located internally compared to the sheath cells (Taiz \& Zeiger, 2004). The movement of larger molecules, such as herbicides, would likely be limited through membranes; even molecules with only four carbon (ie: malate or aspartate), which are responsible for translocating $\mathrm{CO}_{2}$ fixed in the mesophyll to the sheath cells in the vascular bundle, are dependent on translocation via plasmodesmata (Figure 7). The translocation of malate from mesophyll to cells at the vascular bundle sheath is between 100 and 1,000 times greater than the maximum allowed translocation via biological membranes (Buchanan et al., 2005).

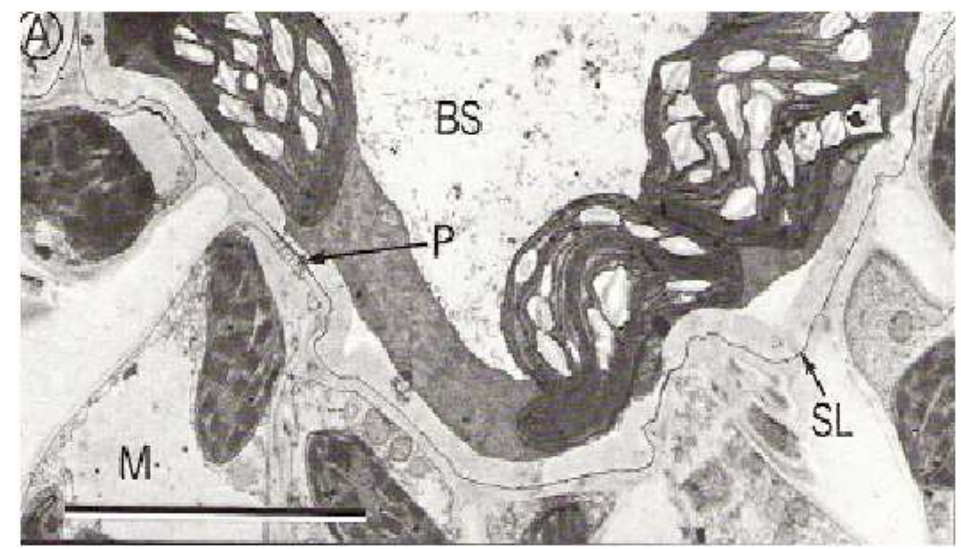

Fig. 7. Vascular bundle sheath (BS) and mesophyll (M) cells of sugarcane. It is possible to observe the suberized layer (SL) in the primary wall of the bundle sheet cells and punctuated spot with a plasmodesmata(P) crossing it. Source: Osmond \& Smith (1976). 
Sterling et al. (1990), who worked with symplastic and apoplastic translocation of bentazon, determined that the translocation of this herbicide molecule was reduced by an application of exogenous CCCP, a metabolic inhibitor (Wagatsuma, 1983; Zhang \& Taylor, 1991; Rincon \& Gonzales, 1992). These researchers associated the reduction in translocation of bentazon with the increase in the gradient of protons between neighboring cells. Presently, it is common knowledge that CCCP acts on the functional control of a cell as a whole; increased concentration of CCCP may result in the reduced capacity of translocation through plasmodesmata (Buchanan et al., 2005). In addition, Sterling et al. (1990) discussed the possibilities of bentazon broadcasting through membranes by considering possible ways of movement, such as simple diffusion, facilitated diffusion, use of carriers, and competition by a carrier between different subtracts. However, these types of translocation usually occur when cells of the same domain show similar concentrations of the herbicide between them and higher concentrations than the external environment. In this scenario, the herbicide is translocated through membranes, reaching cells from other symplastic domains to all others in the same domain by direct cytoplasmic connections. It would be incorrect to assume that a relatively large organic molecule, such as an herbicide, would prefer to cross two cell walls and two plasma membranes instead of being carried by a continuous cytoplasmic tube between cells in the same domain.

Another study describes the application of 10 droplets of chlorsulfuron on the third definitive leaf of a seedling of field pennycress (Thlaspi arvense) with five definitive leaves (Bestman et al., 1990). Chlorsulfuron is an herbicide that belongs to the group of sulfonylurea, inhibitor of the enzyme acetolactate synthase (ALS), involved in the synthesis of branched-chain amino acid valine, leucine, and isoleucine (Leite et al., 1998). The rate of efflux of photosynthates from leaves that did not receive a direct application of the herbicide in treated plants was reduced only 24 hours after the application of chlorsulfuron. Movement of this herbicide was slow, indicating either that xylem and phloem were probably not the preferential translocation pathways, or that the herbicide took too long to reach xylem and phloem. Translocation probably occurred between cells due to the fact that cells from different sheets are relatively distant, which means they would not belong to the same symplastic domain. In this case, translocation across membranes associated with the phloem may have been significant.

ALS-inhibiting herbicides can use characteristics of dissociation to act more efficiently in cells belonging to the same domain. As the $\mathrm{pH}$ in the exterior of the cell is approximately 5.5, ALS-inhibiting herbicides are in a non-dissociated form and are thus able to penetrate the cell more easily. Once at the cytoplasm, where the medium is more alkaline $(\mathrm{pH}$ approximately 7.5), these herbicides disassociate and turn into the most active, and less capable, translocating form of the molecule. Because the dissociated form is less capable of spreading to the exterior of the cell, the molecules of these herbicides get "stuck" in the cytoplasm; this behavior receives the name "ionic trap" (Vidal, 2002). In this situation, the herbicide moves freely among cells of the same domain because, in essence, "a single cytoplasm occurs" between cells of the same domain (Crawford \& Zambryski, 2001). Penetration of these herbicides in a single cell enables their distribution to all other cells belonging to the same symplastic domain (Jachetta et al., 1986). In addition, plasmodesmata may have significant participation in translocation of molecules that have pKa (dissociation constant) below the $\mathrm{pH}$ of the xylem, which is approximately 5.5; it may also assist symplastic movement of these molecules by other routes besides phloem (Vidal, 2002). 
The movement through plasmodesmata is relevant also in translocation of macromolecules that carry information (RNA) to neighboring cells. In this way, the behavior of cells in a given domain is not isolated, which can thus act as a functional unit (Jorgensen \& Lucas, 2006; Lucas et al., 2009). Although studies related to plasmodesmata and herbicides are limited, information of movement of other macromolecules similar in size to herbicidal molecules can be adapted. In a trial that grafted tomato plants, the data determined that a macromolecule which carries information responsible for a leaf's deformation, known as "Mouse's Ear", encoded at the roots of the rootstock, reached the meristem of the graft, and caused the deformation (Kim et al., 2001). Since this compound was not translocated via the transpiratory pathway, the most probable route of translocation identified by the researchers was through cytoplasmic connections of cells both within the same domain and between interactions of different domains (Figure 8). The data highlighted the participation of plasmodesmata in the long-distance translocation of the molecule.

Being known the capacity of molecules to move cell-by-cell, the acropetal long-distance translocation of herbicides can occur by apoplast (xylem) or via symplast (plasmodesmata), provided that the characteristics of the molecule in relation to polarity, electric charge and dimensions, allow this translocation. Even the translocation in the phloem is accomplished through plasmodesmata present in the interface between phloem cells. If the pesticide was applied to the surface of the plant and was correctly absorbed, and this plant later is submitted to moderate water stress that causes closure of stomata and a consequent reduction of translocation by xylem, herbicide can still be translocated at some rate via plasmodesmata (Alberts et al., 1999). In most plants, translocation of glyphosate is typically fast as it is essential for herbicidal activity. After penetration in leaves, glyphosate may be translocated both by phloem sieve tubes, which also involves plasmodesmata, and cell-tocell in the same symplastic domain via plasmodesmata, reaching all cells of the domain quickly (Franz et al., 1997; Jachetta et al., 1986). In fact, both translocations are complementary and non-competitive due to the fact that plasmodesmata act on loading and unloading the phloem (Sowinski et al., 2003). Glyphosate is one of the few studies where herbicide translocation via plasmodesmata is considered.

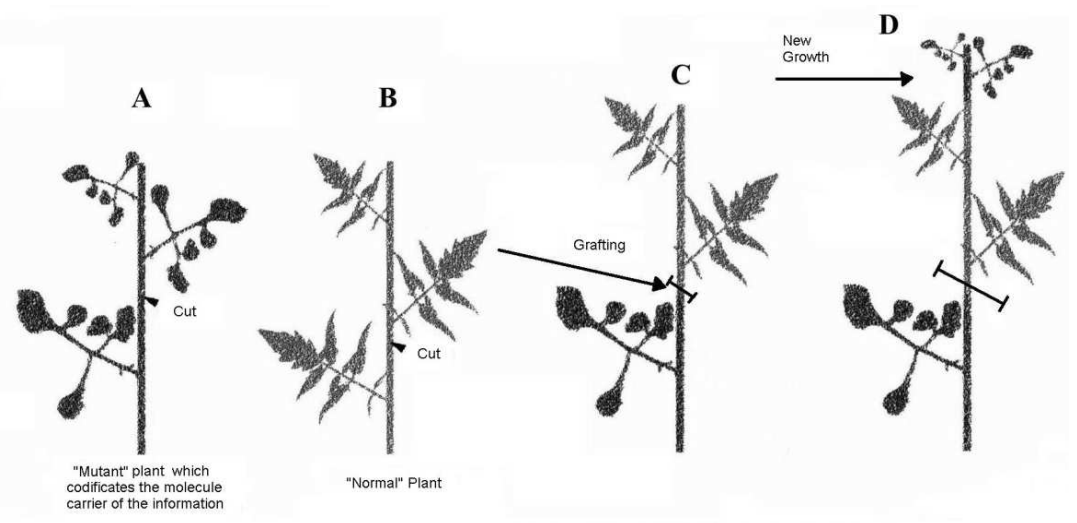

Fig. 8. Study showing the movement of informational substances codified at the roots of the rootstock and carried to the meristem of the graft, where the mutation known as "Mouse's Ear" was present on the newly developed leaves. Source: Adapted from Kim et al. (2001). 
There are also translocation differences depending on the $\mathrm{pH}$ of the solution in which the herbicide is diluted. In one study involving absorption and translocation of sulfentrazone and glyphosate by plant roots, research determined that with the solution's decrease in $\mathrm{pH}$, absorption of sulfentrazone increased, along with its solubility (Ferrell et al., 2003). In turn, glyphosate was not as dependent on $\mathrm{pH}$. While the $\mathrm{pKa}$ of sulfentrazone was 6.5, glyphosate had a sequence of $\mathrm{pKa}(0.8,2.3,6.0$, and 11.0), which shows different configurations as a function of the $\mathrm{pH}$ (Grey et al., 2000; Sprankle et al., 1975, Coutinho \& Mazo, 2005). It is believed that at physiological $\mathrm{pH}$, glyphosate is considered a zwitterion, behaving as a divalent anion with the possibility of being strongly complex with some divalent metal cations (Devine et al., 1993). This molecule has the ability of changing poles when it reaches the cytoplasm, acquiring a net negative charge promoted by deprotonation due to physiological $\mathrm{pH}$, and contributing to its retention in the symplast (Wauchope, 1976). Even with this behavior, absorption and translocation of glyphosate was less affected by the $\mathrm{pH}$ than sulfentrazone. The role of plasmodesmata in glyphosate translocation is known, indicating that they act not only in conjunction with vascular system, but also in a semiautonomous way (Jachetta et al., 1986). These characteristics are particularly important for the translocation of soil-applied herbicides where xylem has an important - but not exclusive - role in the translocation of these macromolecules.

\section{Herbicide translocation and plasmodesmata in older plants}

Older plants have greater dry mass, leaf area, and, consequently, a greater transpiratory rate. For example, consider a barnyard grass (Echinochloa crusgalli) seedling with $3-4$ leaves, when herbicide is typically applied, and another plant at the stage of $2-3$ tillers; both plants may present high metabolic rates because they are in full growth, but the numerical volume of acropetal water flow is surely higher in the plant at the stage of $2-3$ tillers under the same environmental conditions (Taiz \& Zeiger, 2004). When using a soil-applied herbicide, which is absorbed by the roots of both plants, it would be efficiently translocated via xylem due to the high transpiratory flow in both plants. However, the barnyard grass plant at the stage of $2-3$ tillers is less susceptible to the herbicide than the plant with $2-4$ leaves. Besides the causes already discussed by Vidal et al. (2002), in mature cells in a plant in active growth, the SEL of plasmodesmata is smaller and herbicide movement is more dependent upon the transpiratory flux. Symplastic translocation of molecules via plasmodesmata in these cells is severely reduced; in comparison to when the cell is developing and has the ability to exchange essential informational molecules, ions, and regulators, the SEL may be up to 50 times lower when the cell is mature and does not require a large influx of molecules (Oparka \& Roberts, 2001).

As previously discussed, the SEL of a plasmodesma allows relatively free passage of molecules as large as $1 \mathrm{kDa}$ through young organs. Considering the SEL can be reduced to approximately 50 times lower, a mature plant plasmodesmatal SEL may only, in general terms, allow passage of molecules around 20 - 50 Daltons (Da). Most herbicide molecules are bigger than $100 \mathrm{Da}$ and smaller than $500 \mathrm{Da}$ (Table 1). This information strongly suggests that plasmodesmatal reduction in SEL is one of the great responsibilities due to lower susceptibility of older plants to herbicides. As previously discussed, the SEL can be of smaller importance if the herbicidal molecule presents some degree of affinity with carrier proteins embedded in the inner surface of the plasmodesmata. This affinity may allow distinct rates of movement through plasmodesmata for herbicidal molecules of similar size. 
Movement deficiency, which is caused by reduced absorption and/or translocation, of a given herbicide within the plant may be the reason for herbicide tolerance and/or selectivity in many crops and weed species (Hess, 1985; Ladlie, 1991). In addition, different rates of herbicide translocation, acropetaly or basipetaly, may result from alterations made at the genetic level and confer resistance to a plant due to an active ingredient usually lethal to that species. Reduced translocation of herbicides as a mechanism of resistance is extensively researched, and was identified for example, in Italian ryegrass (Lolium multiflorum) and Wimmera ryegrass (Lolium rigidum) (Ferreira et al, 2006; Lorraine-Colwill et al, 2002). Other plants, however, do not show differences in relation to the absorption and translocation of herbicides between resistant and susceptible biotypes (Carey et al., 1995; Dias et al., 2003). In cases where reductions on herbicide translocation occur, it is essential to investigate whether there is a reduction of plasmodesmata SEL or reduction in the association with its function of phloem loading/unloading. In addition, for herbicides carried via xylem and/or phloem, the role of plasmodesmata in acropetal translocation is essential in the same way it is for other organic molecules (Taiz \& Zeiger, 2004).

The size of herbicidal molecules usually is not a limiting factor for translocation via plasmodesmata in younger plants because it generally lies between $150 \mathrm{Da}$ and $450 \mathrm{Da}$ (Table 1), and molecules up to $1 \mathrm{kDa}$ usually have relatively free passage through plasmodesmata in younger plants (Taiz \& Zeiger, 2004). However, size can be a limiting factor in older plants, as previously discussed. Herbicidal molecules are typically smaller than many proteins or enzymes translocated via plasmodesmata, and proteins that have a role in translocating other substances through the plasmodesmata, such as protein MP30, connected to the v-RNA (viral RNA), which makes traffic possible (Kragler et al., 2003). Besides size, other characteristics of molecules, such as electrical charges, can be important and can allow the passage of certain molecules in lieu of others (Devine \& Hall, 1990).

\section{Plasmodesmata and herbicide translocation under water stress}

When plants are subjected to stress, metabolic reactions tend to decrease proportionally. Because herbicides are less translocated and, as a consequence, become more available to reactions of metabolization, conjugation, or trapping, many herbicides have their action strongly reduced if plants are under stress before or after application (Cataneo et al., 2003). In auxin-like herbicides, the herbicidal activity is typically resumed when metabolism is increased after water stress. Auxin-like substances previously either applied (synthetic) or produced (natural) are able to reach the site of action after stress is removed and the plant reaches the usual state of turgescence (Drake \& Carr, 1978). Although plasmodesmata are not the only route of translocation these substances take, they can play an important role in the translocation of auxin-like herbicides, and possibly other classes of herbicides, under moderate water stress.

\section{Conclusions and new insights}

In order to determine if a given compound, or chemical group, has the ability to manipulate the size exclusion limit of the canal, mainly when it is reduced as the plant ages, more studies are needed to clarify the existence of affinity between certain herbicidal molecules and proteins embedded in the inner surface of plasmodesmata. Proved existence of such an affinity may favor molecular translocation, regardless of its size. Studies also need to be 


\begin{tabular}{|c|c|c|c|c|c|}
\hline $\begin{array}{l}\text { Chemical } \\
\text { Structure }\end{array}$ & $\begin{array}{l}\text { Common Name } \\
\text { And Formula }\end{array}$ & $\begin{array}{l}\text { Size } \\
(\mathrm{Da})^{\mathrm{a}}\end{array}$ & $\begin{array}{l}\text { Chemical } \\
\text { Structure }\end{array}$ & $\begin{array}{l}\text { Common Name } \\
\text { And Formula }\end{array}$ & $\begin{array}{l}\text { Size } \\
(\mathrm{Da})^{\mathrm{a}}\end{array}$ \\
\hline & $\begin{array}{c}\text { Atrazine } \\
\mathrm{C}_{8} \mathrm{H}_{14} \mathrm{ClN}_{5}\end{array}$ & 215.7 & & $\begin{array}{l}\text { Bispyribac- } \\
\text { sodium } \\
\mathrm{C}_{19} \mathrm{H}_{18} \mathrm{~N}_{4} \mathrm{O}_{8}\end{array}$ & 430.2 \\
\hline & $\begin{array}{l}\text { Ametrine } \\
\mathrm{C}_{9} \mathrm{H}_{17} \mathrm{~N}_{5} \mathrm{~S}\end{array}$ & 227.3 & & $\begin{array}{c}\text { Quinclorac } \\
\mathrm{C}_{10} \mathrm{H}_{5} \mathrm{Cl}_{2} \mathrm{NO}_{2}\end{array}$ & 242.0 \\
\hline & $\begin{array}{c}\text { Nicosulfuron } \\
\mathrm{C}_{15} \mathrm{H}_{18} \mathrm{~N}_{6} \mathrm{O}_{6} \mathrm{~S} . \mathrm{H}_{2} \\
\mathrm{O}\end{array}$ & 428.4 & 管, & $\begin{array}{l}\text { Sucrose } \\
\mathrm{C}_{12} \mathrm{H}_{22} \mathrm{O}_{11}\end{array}$ & 342.3 \\
\hline & $\begin{array}{l}\text { Glyphosate } \\
\text { (acid eqv.) } \\
\mathrm{C}_{3} \mathrm{H}_{8} \mathrm{NO}_{5} \mathrm{P}\end{array}$ & 169.1 & & $\begin{array}{l}\text { Malate } \\
\mathrm{C}_{4} \mathrm{H}_{6} \mathrm{O}_{5}\end{array}$ & 134.1 \\
\hline & $\begin{array}{c}\text { Trifloxysulfuron } \\
- \\
\text { sodium } \\
{ }_{-} \mathrm{C}_{14} \mathrm{H}_{13} \mathrm{~F}_{3} \mathrm{~N}_{5} \mathrm{O}_{6} \mathrm{SN} \\
\text { a }\end{array}$ & 459.3 & 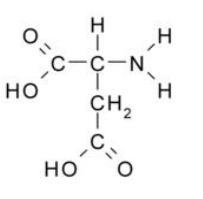 & $\begin{array}{l}\text { Aspartate } \\
\mathrm{C}_{4} \mathrm{H}_{7} \mathrm{NO}_{4}\end{array}$ & 133.0 \\
\hline & $\begin{array}{c}\text { Sulfentrazone } \\
\mathrm{C}_{11} \mathrm{H}_{10} \mathrm{Cl}_{2} \mathrm{~F}_{2} \mathrm{~N}_{4} \mathrm{O}_{3} \\
\mathrm{~S}\end{array}$ & 387.1 & -- & PEP carboxilase ${ }^{b}$ & $2.7 \times 10^{5}$ \\
\hline & $\begin{array}{c}\text { Bentazon } \\
\mathrm{C}_{10} \mathrm{H}_{12} \mathrm{~N}_{2} \mathrm{O}_{3} \mathrm{~S}\end{array}$ & 240.3 & $-\cdots$ & v-RNA MP30c & $3 \times 10^{4}$ \\
\hline & $\begin{array}{c}\text { 2,4-D (eq. ácido) } \\
\mathrm{C}_{8} \mathrm{H}_{6} \mathrm{Cl}_{2} \mathrm{O}_{3}\end{array}$ & 221.0 & - & K & 39.1 \\
\hline & $\begin{array}{c}\text { Penoxsulam } \\
\mathrm{C}_{16} \mathrm{H}_{14} \mathrm{~F}_{5} \mathrm{~N}_{5} \mathrm{O}_{5} \mathrm{~S}\end{array}$ & 483.2 & -- & $\mathrm{Na}$ & 23.0 \\
\hline
\end{tabular}

a Original data calculated from the chemical formulas; ${ }^{b}$ Source: Patel et al. (2004); c Source: Wolf et al. (1989); Kragler et al. (2003).

Table 1. Dimensions of some herbicidal molecules, compounds, proteins, and ions. Federal University of Viçosa, Brazil, 2010 
devoted to determine if the degree of similarity between a given herbicidal molecule and a natural plant compound (such as for auxin-like herbicides) results in higher translocation rates through symplast. More research should also be given to the participation of plasmodesmata in the movement of systemic herbicides within the plant. Studies with radioactively-marked products, and the intensification of research on herbicide physiology, will help explain many aspects not fully understood involving herbicidal translocation via xylem and phloem, and their association with the apoplast and symplastic domains.

\section{References}

ALBERTS, B. et al. Fundamentos da biologia celular. Porto Alegre: Artes Médicas Sul, 1999. $757 \mathrm{p}$.

BESTMAN, H. D.; DEVINE, M. D.; BORN, W. H. V. Herbicide chlorsulfuron decreases assimilate translocation out of treated leaves of field pennycress (Thlaspi arvense L.) seedlings. Plant Physiol., v. 93, p. 1441-1448, 1990.

BUCHANAN, B. B.; GRUISSEM, W.; JONES, R. L. Biochemistry \& molecular biology of plants. Rockville: American Society of Plant Physiologists, 2005. 1367 p.

CAREY, V. F. et al. Resistance mechanism of propanil-resistant barnyardgrass. I. Absorption, translocation, and site of action studies. Pestic. Biochem. Physiol., v. 52, p. 182-189, 1995.

CATANEO, A. C. et al. Glutathione S-transferase activity on the degradation of the herbicide glyphosate in maize (Zea mays) plants. Planta Daninha, v. 21, p. 307-312, 2003.

CHAMEL, A. Foliar uptake of chemicals studied with whole plants and isolated cuticles. In: NEUMANN, P. M. (Ed.). Plant growth and leaf-applied chemicals. Boca Raton: CRC Press, 1988. p. 27-50.

COUTINHO, C. F. B.; MAZO, L. H. Metallic complexes with glyphosate: a review. Quím. Nova, v. 28, p. 1038-1045, 2005.

CRAWFORD, K. M.; ZAMBRYSKI, P. C. Non-targeted and targeted protein movement through plasmodesmata in leaves in different developmental and physiological status. Plant Physiol., v. 125, p. 1802-1812, 2001.

DENIS, M. H.; DELROT, S. Carrier-mediated uptake of glyphosate in broad bean (Vicia faba) via a phosphate translocationer. Plant Physiol., v. 87, p. 569-575, 1993.

DEVINE, M. D.; HALL, L. M. Implications of sucrose translocation mechanisms for the translocation of herbicides. Weed Sci., v. 38, p. 299-304, 1990.

DEVINE, M. D.; DUKE, S. O.; FEDTKE, C. Physiology of herbicide action. Englewood Cliffs: Prentice Hall, 1993. 441 p.

DIAS, N. M. P. et al. absorption and translocation of herbicide diuron by species susceptible and tolerant grass mattress (Digitaria spp.). Planta Daninha, v. 21, p. 293-300, 2003.

DRAKE, G.; CARR, D. J. Plasmodesmata, tropism, and auxin translocation. J. Cat. Bot., v. 29, p. $1309-1318,1978$.

FERREIRA, F. A.; SILVA, A. A.; GALON, L.; CONCENÇO, G.; FERREIRA, E. A. Mecanismos de ação de herbicidas. In: ZAMBOLIN, L.; PINANÇO, M. C.; SILVA, A. A.; FERREIRA, L. R.; FERREIRA, F. A.; JESUS Jr., W. C. J. (Eds.). Produtos fitossanitários. Viçosa: UFV, 2008. p.349-383. 
FERREIRA, E. A. et al. Translocation of glyphosate in ryegrass biotypes (Lolium multiflorum). Planta Daninha, v. 24, p. 365-370, 2006.

FERRELL, J. A.; WITT, W. W.; VENCILL, W. K. Sulfentrazone absorption by plant roots increases the soil or solution pH decreases. Weed Sci., v. 51, p. 826-830, 2003.

FRANZ, J. E.; MAO, M. K.; SIKORSKI, J. A. Uptake, translocation and metabolism of glyphosate in plants. In: Glyphosate: a unique global herbicide. Washington: American Chemical Society, 1997. p. 143-181.

GOUGLER, J. A.; GEIGER, D. R. Uptake and distribution of N-phosphonomethylglycine in sugar beet plants. Plant Physiol., v. 68, p. 668-672, 1981.

GREY, T. L. et al. Behavior of sulfentrazone in ionic exchange resins, electrophoresis gels, and cation-saturated soils. Weed Sci., v. 48, p. 239-247, 2000.

HAGER, A. G.; SPRAGUE, C. L. A contemporary, color-enhanced herbicide site of action bulletin. Journal of Extension, v.40, n.2, ON-LINE, ISSN 1077-5315.

HANNAHS, G. Plasmodesmata. Gambier: Kenyon College, 1997. On-line at http://biology.kenyon.edu/edwards/project/greg/pd.htm

HATCH, M. D.; SLACK, C. R. The C4-carboxylic acid pathway of photosynthesis. In: REINHOLD, L.; LIWSCHITZ, Y. (Eds.). Progress in phytochemistry. London: Wiley-Interscience, 1970. p. 35-106.

HAY, J. R. Herbicide translocation in plants. In: AUDUS, L. J. (Ed.). Herbicides physiology, biochemistry, ecology. V.1, 1976. p.365-393.

HESS, F. D. Herbicide absorption and translocation and their relationship to plant tolerance and susceptibility. In: DUKE, S. O. (Ed.). Weed physiology. Boca Raton: CRC Press, 1985. p. 192-214.

JACHETTA, J. J.; APPLEBY, A. P.; BOERSMA, L. Apoplastic and symplastic pathways of atrazine and glyphosate translocation in shoots of seedling sunflower. Plant Physiol., v. 82, p. 1000-1007, 1986.

JORGENSEN, R. A.; LUCAS, W. J. Movement of macromolecules in plant cells through plasmodesmata. Sci. STKE, 2006. <http://www.ncbi.nlm.nih.gov/entrez/> query.fcgi?cmd=Retrieve\&db=PubMed\&list_uids /=16493020\&dopt=Abstract.

KIM, M. et al. Developmental changes due to long-distance movement of a homeobox fusion transcript in tomato. Science, v. 293, p. 287-289, 2001.

KRAGLER, F.; LUCAS, W. J.; MONZER, J. Plasmodesmata: dynamics, domains and patterning. Ann. Bot., v. 81, p. 1-10, 1998.

KRAGLER, F. et al. MPB2C, a microtubule-associated plant protein binds to and interferes with cell-to-cell translocation of Tobacco Mosaic Virus movement protein1. Plant Physiol., v. 132, p. 1870-1883, 2003.

LADLIE, J.S. Guide to herbicide injury symptoms in soybean with "look-alike" symptoms. Hollamdale: Agri-Growth Research, 1991. 86 p.

LEITE, C. R. F.; ALMEIDA, J. C. V.; PRETE, C. E. C. Aspectos fisiológicos, bioquímicos e agronômicos dos herbicidas inibidores da ALS (AHAS). Londrina: Grafmark, 1998. $68 \mathrm{p}$.

LORRAINE-COLWILL, D. F. et al. Investigations into the mechanism of glyphosate resistance in Lolium rigidum. Pestic. Biochem. Physiol., v. 74, p. 62-72, 2002. 
LUCAS, W. J.; HAM, B. K.; KIM, J. Y. Plasmodesmata - bridging the gap between neighboring plant cells. Trends in Cell Biology, v.19, n.10, p.495-503, 2009. ISSN 0962-8924.

LUCAS, W. J.; DING, B.; SCHOOT, C. V. D. Plasmodesmata and the supracellular nature of plants. New Phytologist, v.125, p.435-476, 1993.

MÜNCH, E. Die Stoffbewegunen in der Pflanze. Jena: Verlag von Gustav Fischer, 1930. 234p.

NEUMANN, P. M. Agrochemicals: plant physiological and agricultural perspectives. In: NEUMANN, P. M. (Ed.). Plant growth and leaf-applied chemicals. Boca Raton: CRC Press, 1988. p. 1-13.

OPARKA, K. J.; ROBERTS, A. Plasmodesmata. A not so open-and-shut case. Plant Physiol., v. 125, p. 123-126, 2001.

OSMOND, C. B.; SMITH, F. A. Symplatic translocation of metabolites during $\mathrm{C}_{4^{-}}$ photosynthesis. In: GUNNING, B. E. S.; ROBARDS, A. W. (Eds.). Intercellular communication in plants: studies on plasmodesmata. New York: Springer-Werlag, 1976. p. 229-241.

PATEL, H. M.; KRASZEWSKI, J. L.; MUKHOPADHYAY, B. The phosphoenolpyruvate carboxylase from Methanothermobacter thermautotrophicus has a novel structure. J. Bacteriol., v. 186, p. 5129-5137, 2004.

RINCON, M.; GONZALES, R.A. Aluminum partitioning in intact roots of aluminumtolerant and aluminum-sensitive wheat (Triticum aestivum L.) cultivars. Plant Physiol., v. 99, p. 1021-1028, 1992.

ROBARDS, A. W. Plasmodesmata in higher plants. In: GUNNING, B. E. S.; ROBARDS, A. W. (Eds.). Intercellular communication in plants: studies on plasmodesmata. New York: Springer-Werlag, 1976. p. 15-57.

SILVA, J. F.; SILVA, J. F.; FERREIRA, L. R.; FERREIRA, F. A. Herbicidas: absorção, translocação, metabolismo, formulação e misturas. In: SILVA, A. A.; SILVA, J. F. (Eds.). Tópicos em manejo de plantas daninhas. Viçosa: UFV, 2007. p.149-188.

SOWINSKI, P.; RUDZISKA-LANGWALD, A.; KOBUS, P. Changes in plasmodesmata frequency in vascular bundles of maize seedling leaf induced by growth at suboptimal temperatures in relation to photosynthesis and assimilate export. Environ. Exp. Bot., v. 50, p. 183-196, 2003.

SPRANKLE, P.; MEGGITT, W. F.; PENNER, D. Adsorption, mobility, and microbial degradation of glyphosate in the soil. Weed Sci., v. 23, p. 229-234, 1975.

STERLING, T.M.; BALKE, N. E.; SILVERMAN, D. S. Uptake and accumulation of the herbicide bentazon by cultured plant cells. Plant Physiol., v. 92, p. 1121-1127, 1990.

TAIZ, L.; ZEIGER, E. Fisiologia vegetal. Porto Alegre: ARTMED, 2004. 750 p.

TAN, B.L. et al. Localization and movement of mineral oil in plants by fluorescence and confocal microscopy. J. Exp. Bot., v. 56, p. 2755-2763, 2005.

TERRY, B. R.; ROBARDS, A. W. Hydrodynamic radius alone governs the mobility of molecules through plasmodesmata. Planta, v. 171, p. 145-157, 1987.

TYREE, M. T.; PETERSON, C. A.; EDGINGTON, L. V. A simple theory regarding ambimobility of xenobiotics with special reference to nematicide oxamyl. Plant Physiol., v. 63, p. 367-374, 1979. 
VIDAL, R. A. Ação dos herbicidas. Porto Alegre: Universidade Federal do Rio Grande do Sul, 2002. 89 p.

WAGATSUMA, T. Effect of non-metabolic conditions on the uptake of aluminum by plant roots. Soil Sci. Plant Nutr., v. 29, p. 323-333, 1983.

WAUCHOPE, D. Acid dissociation constants of arsenic acid, methylarsonic acid (MAA), dimethylarsinic acid (cacodylic acid), and n-(phosphonomethyl)glycine (glyphosate). J. Agric. Food Chem., v. 24, p. 717-721, 1976.

ZHANG, G. C.; TAYLOR, G. J. Effects of biological inhibitors on kinetics of aluminum uptake by excised roots and purified cell-wall material of aluminum-tolerant and aluminum-sensitive cultivars of Triticum aestivum L. J. Plant Physiol., v. 138, p. 533-539, 1991.

WOLF, S. et al. Movement protein of tobacco mosaic virus modifies plasmodesmatal size exclusion limit. Science, v. 246, p. 377-349, 1989. 


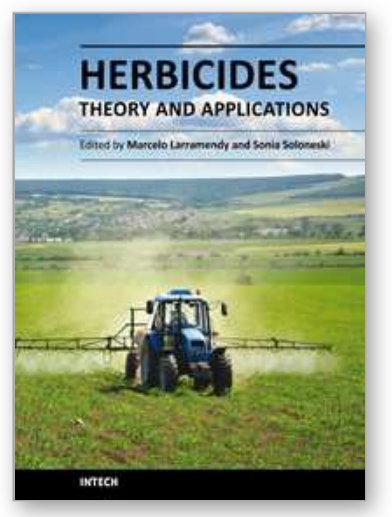

\author{
Herbicides, Theory and Applications \\ Edited by Prof. Marcelo Larramendy
}

ISBN 978-953-307-975-2

Hard cover, 610 pages

Publisher InTech

Published online 08, January, 2011

Published in print edition January, 2011

The content selected in Herbicides, Theory and Applications is intended to provide researchers, producers and consumers of herbicides an overview of the latest scientific achievements. Although we are dealing with many diverse and different topics, we have tried to compile this "raw material" into three major sections in search of clarity and order - Weed Control and Crop Management, Analytical Techniques of Herbicide Detection and Herbicide Toxicity and Further Applications. The editors hope that this book will continue to meet the expectations and needs of all interested in the methodology of use of herbicides, weed control as well as problems related to its use, abuse and misuse.

\title{
How to reference
}

In order to correctly reference this scholarly work, feel free to copy and paste the following:

Germani Concenco and Leandro Galon (2011). Plasmodesmata: Symplastic Transport of Herbicides Within the Plant, Herbicides, Theory and Applications, Prof. Marcelo Larramendy (Ed.), ISBN: 978-953-307-975-2, InTech, Available from: http://www.intechopen.com/books/herbicides-theory-and-applications/plasmodesmatasymplastic-transport-of-herbicides-within-the-plant

\section{INTECH}

open science | open minds

\section{InTech Europe}

University Campus STeP Ri

Slavka Krautzeka 83/A

51000 Rijeka, Croatia

Phone: +385 (51) 770447

Fax: +385 (51) 686166

www.intechopen.com

\section{InTech China}

Unit 405, Office Block, Hotel Equatorial Shanghai

No.65, Yan An Road (West), Shanghai, 200040, China

中国上海市延安西路65号上海国际贵都大饭店办公楼405单元

Phone: +86-21-62489820

Fax: $+86-21-62489821$ 
(C) 2011 The Author(s). Licensee IntechOpen. This chapter is distributed under the terms of the Creative Commons Attribution-NonCommercialShareAlike-3.0 License, which permits use, distribution and reproduction for non-commercial purposes, provided the original is properly cited and derivative works building on this content are distributed under the same license. 